\title{
What is a healthy Nordic diet? Foods and nutrients in the NORDIET study
}

\author{
Viola Adamsson'*, Anna Reumark², Tommy Cederholm!, \\ Bengt Vessby', Ulf Risérus' and Gunnar Johansson ${ }^{3}$
}

\author{
'Clinical Nutrition and Metabolism, Department of Public Health and Caring Sciences, Uppsala University, Uppsala, \\ Sweden; 'Lantmännen Food R\&D AB, Malmö, Sweden; ${ }^{3}$ School of Social and Health Sciences, Halmstad University, \\ Halmstad, Sweden
}

Abstract

Background: A healthy Nordic diet (ND), a diet based on foods originating from the Nordic countries, improves blood lipid profile and insulin sensitivity and lowers blood pressure and body weight in hypercholesterolemic subjects.

Objective: To describe and compare food and nutrient composition of the ND in relation to the intake of a Swedish reference population (SRP) and the recommended intake (RI) and average requirement (AR), as described by the Nordic nutrition recommendations (NNR).

Design: The analyses were based on an estimate of actual food and nutrient intake of 44 men and women (mean age $53 \pm 8$ years, BMI 26 \pm 3 ), representing an intervention arm receiving ND for 6 weeks.

Results: The main difference between ND and SRP was the higher intake of plant foods, fish, egg and vegetable fat and a lower intake of meat products, dairy products, sweets and desserts and alcoholic beverages during ND ( $p<0.001$ for all food groups). Intake of cereals and seeds was similar between ND and SRP $(p>0.3)$. The relative intake of protein, fat and carbohydrates during ND was in accordance with RI. Intake of all vitamins and minerals was above AR, whereas sodium intake was below RI.

Conclusions: When compared with the food intake of an SRP, ND is primarily a plant-based diet. ND represents a balanced food intake that meets the current RI and AR of NNR 2004 and has a dietary pattern that is associated with decreased morbidity and mortality.

Keywords: Nordic foods; nutrient intake; food intake; Swedish reference population; Nordic nutrition recommendations

Received: I5 March 2012; Revised: I4 May 2012; Accepted: I June 2012; Published: 27 June 2012

A ccording to the NORDIET study (1), the Nordic diet (ND), mainly based on traditional Nordic foods, improved blood lipid profiles and insulin sensitivity and lowered blood pressure and body weight in hypercholesterolemic subjects. These results are in accordance with a controlled study in pre-diabetic subjects suggesting reduction of inflammatory and endothelial function markers (2) and improved glucose metabolism (3) after a diet high in Nordic foods, including whole grains, fish and bilberries. The favourable effects of ND support current international dietary guidelines (4) and dietary guidelines in Europe $(5,6)$ and the United States (7-9). The ND is in accordance with similar healthy diets, such as DASH and the Mediterranean diets (10-13). Although the focus of ND is cardiovascular risk reduction, this diet would probably be of benefit in the prevention of type 2 diabetes $(14,15)$ and several forms of cancer (16).
A recent meta-analysis by Sofi et al. (13) suggests that the Mediterranean diet is beneficial for the primary prevention of several chronic diseases, such as cardiovascular diseases (CVD), cancer, Parkinson's and Alzheimer's disease. A Danish cohort study (17) suggests a lower risk of mortality among middle-aged Danes who adhere to a healthy Nordic food index, and a description of guidelines for a New ND, emphasising health, sustainability and gastronomy, has been published (18). As the reported health effects of ND appear promising, further detailed characterisation of the food and nutrient profile of ND is warranted.

The objective of this study was to describe and compare the food and nutrient composition of the ND in relation to the intake of a Swedish reference population (SRP) and to the recommended intake (RI) and average requirement (AR), as described by reference (6). 


\section{Methods}

\section{Design}

The study design is described elsewhere (1). In brief, the trial was a 6-week dietary randomised, controlled, parallel-group intervention study, including free-living subjects $(n=86)$. At baseline, the subjects were randomised into one of two groups: ND $(n=44)$ or a control diet $(n=42)$. The current study was based on the ND provided to the 44 subjects in the intervention group (17 men and 27 women, mean age $53 \pm 8$ years, mean BMI 26.3 \pm 3 ). All subjects followed a 3-week rotating menu plan, including alternatives for breakfast, lunch, dinner, snack and beverage. A representative daily menu for the ND is presented in supplemental material (1) Table 1. Throughout the study, all dishes were prepared and supplied to study participants randomised to ND, except for breakfast, which the subjects prepared themselves. The participants were allowed to eat food outside the menu, once a week, provided the meal or snack was registered. The ND was provided ad libitum and was neither energy restricted nor isocaloric on an individual level. The ND was calculated on an isocaloric basis (on group level) through validated formulae (6). Dietist XP version 3.0, a computer programme based on the Swedish National Food Administration database 2005-02-01, was used to calculate food and nutrient intake in the ND.

\section{Selection of food items in the ND}

The selection of foods was based on nutritional value, agricultural traditions, seasonal variations and habitual use of food items in the Nordic countries and foods commonly available at local super markets. Approximately $80 \%$ of food items included in ND should be possible to grow in the Nordic countries. Food groups in the study were based on commonly available specific key nutrients inspired by earlier reports (Table 1) (19-21), for instance, rapeseed oil rich in oleic, linoleic and $\alpha$-linolenic acids $(22,23)$. Fish in general, especially fatty fish, was a natural ingredient in ND, and low-fat dairy products (milk, yoghurt and cheese for cooking) $(6,10,24)$, whole grain cereals in general (25-27) and specific whole grain

Table 1. Description of food items included in each food group in the recommended diet, i.e., the planned NORDIET study

\begin{tabular}{|c|c|}
\hline \multicolumn{2}{|l|}{ Food group } \\
\hline $\begin{array}{l}\text { Fruits, berries, vegetables, root } \\
\text { vegetables }\end{array}$ & $\begin{array}{l}\text { Hot or cold as snack, side dish or incorporated into the dish. Includes rose hip, blueberry, lingonberry, apple, pear, } \\
\text { prune, cabbage, cauliflower, brussels sprouts, broccoli, fennel, spinach, kohlrabi, viper's grass, onion, leek, kale, } \\
\text { sugar peas, turnip, carrot, parsnip and beetroot. }\end{array}$ \\
\hline Potatoes & Mainly boiled. \\
\hline Nuts & Mainly almonds. \\
\hline Legumes & Brown beans, yellow and green peas. \\
\hline Meat & Beef, pork, lamb, reindeer and sausage. \\
\hline Poultry & Chicken and turkey. \\
\hline Dairy products & Low-fat drinking milk or fermented milk $(0.5 \%)$. Cheese $(<17 \%)$. \\
\hline Fish & Herring, Baltic herring, mackerel, salmon and a selection of white fish. \\
\hline Eggs & Eggs were used for cooking. \\
\hline Cereals and seeds & $\begin{array}{l}\text { Cereals include soft and hard bread, rich in whole grain from rye and wheat ( } 50 \% \text { whole grain as dry matter) and } \\
\text { low in sodium, i.e. }<\mathrm{I} \% \mathrm{NaCl} \text {, per day. Oat bran rusks were recommended for snacks. For cold breakfast cereals, } \\
\text { muesli and extruded oat bran were advocated. For hot breakfast cereals such as porridge, oat bran, oatmeal or } \\
\text { barley flakes were advocated. } \\
\text { Oat bran porridge was to be consumed for breakfast as a standard. As an option, when pearled oat or barley was } \\
\text { included for lunch, any of the other breakfast alternatives could be consumed. Lunch and dinner cereals, such as } \\
\text { pearled barley and oat (Mathavre, Matkorn), were used instead of traditional rice. Whole grain pasta ( } 50 \% \text { whole } \\
\text { grain per dry matter) or whole grain } \beta \text {-glucan-enriched pasta was included. Seeds, such as linseed, psyllium and } \\
\text { sunflower seeds, were included for breakfast. }\end{array}$ \\
\hline Fat and oil & $\begin{array}{l}\text { Vegetable low fat spread ( } 38 \% \text { fat), with no plant sterols added, for bread, and a vegetable liquid margarine for } \\
\text { cooking }(80 \% \text { fat), both based on vegetable oil (sunflower, linseed and rapeseed oil). Rapeseed oil was used for } \\
\text { dressing. }\end{array}$ \\
\hline Sweets, desserts, coffee bread & Sweet-baked goods based on oat bran. Jam for hot and cold cereals, and rusks. \\
\hline Alcoholic beverages & The subjects' habitual amount of alcoholic beverage. \\
\hline Beverages/liquids (non-alcohol) & Tap water, tea, filtered coffee or instant coffee. Juice based on fruits, berries or vegetables. Low-alcohol beer. \\
\hline Herbs, spices and others & $\begin{array}{l}\text { Parsley, dill, mustard, horseradish and chive were used for sensory improvement. Bullion, mustard, vinaigrette, } \\
\text { cooking wine, spices, soy sauce, oat-based non-dairy creamer, potato starch and yeast. Table salt, when used, had } \\
\text { reduced sodium content. }\end{array}$ \\
\hline
\end{tabular}


cereals based on oat and barley $(28,29)$ and rye $(17,30)$ were recommended. However, some food items commonly regarded as traditional Nordic foods, such as butter and certain types of meat and hard cheese, were not included in the ND for general nutritional and metabolic reasons, e.g., low-density cholesterol (LDL-C) rising effects. As the short-term study did not include all seasons, it was not possible to include all types of foods that otherwise might have been included in a healthy ND.

As cooking practices imply physical, chemical and nutritional changes in the nutritional value of food products, low-temperature cooking methods, such as oven baking and boiling, were the main preparation methods recommended in the ND.

\section{Nutrient profile}

The nutrient profile for the study (1) was based on daily RI, according to NNR 2004, and inspired by earlier reports $(10,13,25,31)$. The emphasis was on the quality of fat and carbohydrate, where the amount, quality and source of dietary fibre, refined cereals versus whole grain cereals and the theory of Glycemic Index (GI) were taken into account.

\section{Food intake in ND compared to an SRP}

Food intake data from 'Riksmaten' were used for comparison. During 1997 and 1998, Statistics Sweden, in co-operation with the National Food Administration, conducted the second and the most recent nationwide Swedish dietary survey (Riksmaten) (32). The survey consisted of a representative sample of 2,000 households. In each household, one person aged between 18 and 74 completed a pre-coded, 7-day record book (32).

To compare the intake of different foods in ND $(n=44)$ with the intake in SRP, the values of SRP needed to be grouped and normalised with respect to gender. In the first step, the mean intake for separate products was summarised into larger categories, when needed. In the second step, the weighted means of men and women were calculated with weights corresponding to the proportion of men and women in the ND. For each group of food items, a single estimate of the mean value for SRP was calculated.

\section{Nutrient intake in ND compared to NNR}

The intake of macronutrients was compared with RI. The RI, according to NNR, is defined as the AR of a population plus a safety margin of two standard deviations (SD). RI is used for planning diets, and AR is appropriate when evaluating the nutritional intake of a group of people. For micronutrients with no AR in the NNR, an AR was calculated. First, the ratio AR/RI was calculated for micronutrients with both AR and RI in NNR, and this was then used to calculate a proxy AR for vitamin $\mathrm{D}$, calcium, magnesium and potassium.

\section{Statistical methods}

SPSS version 18 for Windows was used for the statistical analysis. The mean food intake in the ND was compared with the mean food intake in SRP with student's $t$-test, with the null hypothesis that the mean value for ND was equal to the fix value of SRP for each group of food items. A two-tailed $p<0.05$ was regarded as significant. Food intake is presented as actual amount consumed (mean g/day).

\section{Results}

\section{Food items}

After 6 weeks on the ND $(n=44)$, the most apparent deviation from SRP (Table 2) was the higher absolute intake of fruits, berries, vegetables, root vegetables and potatoes, legumes, fish and egg, fat and oil, and a lower intake of meat products and poultry, dairy products, sweets and desserts and alcoholic beverages $(p<0.001)$ for all food groups. The consumption of cereals and seeds was almost the same for both diets $(p>0.3)$.

\section{Macro- and micronutrients}

After 6 weeks, the relative intake of protein, total fat, carbohydrates, saturated fat (SFA), monounsaturated fat (MUFA) and polyunsaturated fat (PUFA) in ND was in accordance with the planned nutrient profile and RI of the NNR (Table 3). The mean intake of total dietary fibre was approximately twice RI; the total dietary fibre comprised cereal $23 \mathrm{~g}$, vegetables $15 \mathrm{~g}$, fruits $5 \mathrm{~g}$ and legumes $5 \mathrm{~g}$. $\beta$-Glucan and whole grain intake were above the planned nutrient profile for the study.

The corresponding intake of vitamins A, D, E (tocopherol), thiamine, riboflavin, niacin, vitamins B6 and B12, folate and vitamin C was above AR (Table 3). The intake of minerals was above AR for calcium, phosphorous, magnesium, iron, zinc, potassium and selenium (Table 3). Sodium intake was below RI, according to NNR.

\section{Discussion}

A diet mainly based on traditional foods originating from the Nordic countries may be beneficial for health $(1,2$, 17). ND reduces CVD risk factors (1) and in this study appeared to be a diet with a healthy food profile that fulfilled the NNR regarding macro- and micronutrient intake.

The same food items were consumed in both ND and SRP, although in different proportions, except for cereals and seeds. This indicated that foods in the ND were not exclusive foods that could be purchased only in special shops. The most apparent difference between the ND and the SRP was the higher absolute intake of plant foods, such as fruits, berries, vegetables, root vegetables, potatoes and legumes, vegetable fats and oils, and fish and egg, and 
Table 2. The RI per day of certain food groups and food items in the planned Nordic diet (ND). And actual quantity consumed after 6 weeks on ND compared to an SRP ${ }^{\mathrm{a}}$

\begin{tabular}{|c|c|c|c|c|}
\hline Food groups & The RI, i.e., the planned ND & $\begin{array}{l}\text { ND mean } \pm S D \\
\text { Actual quantity } \\
\text { consumed }\end{array}$ & SRP estimate & $p^{\mathrm{b}}$ \\
\hline $\begin{array}{c}\text { Fruits, berries, vegetables, root } \\
\text { vegetables and potatoes }{ }^{c}\end{array}$ & Fruit, berries, vegetables, root vegetables: $\geq 500$ per day & $807^{d} \pm 134$ & 382 & $<0.0001$ \\
\hline Legumes ${ }^{\mathrm{e}}$ & No recommendation & $91 \pm 18$ & 9 & $<0.0001$ \\
\hline Nuts & Mainly almonds: 15 g per day & 14 & $n a^{f}$ & $n a^{f}$ \\
\hline Meat products and poultry ${ }^{g}$ & Meat: $\leq 500$ g per week. Poultry: $\leq 300$ gper week & $89^{h} \pm 10$ & 139 & $<0.0001$ \\
\hline Dairy products ${ }^{i}$ & $\begin{array}{l}\text { Drinking milk and fermented milk: } \leq 5 \mathrm{dl} \text { low-fat milk per day } \\
\text { Cheese: }(<17 \%) \text { could be used for cooking as long as total fat and } \\
\text { quality of fat in the whole diet did not differ from RI }\end{array}$ & $249 \pm 119$ & 366 & $<0.0001$ \\
\hline Fish and egg & $\begin{array}{l}\text { Fish: } 3-5 \text { servings per week corresponding to } 53-89 \mathrm{~g} \text { per day, per } \\
\text { week } \\
\text { Egg: included as long as the intake of cholesterol not exceeded the RI }\end{array}$ & $72 \pm 11$ & 50 & $<0.0001$ \\
\hline Cereals and seeds ${ }^{k}$ & $\begin{array}{l}\text { Bread: } 46 \text { slices of bread per day corresponding to } 160-240 \mathrm{~g} \text { per day } \\
\beta \text {-Glucan-rich food items: food items included to reach the RI of } 3 \mathrm{~g} \\
\text { per day } \\
\text { Lunch cereals: one and a half serving per day } \\
\text { Whole grain pasta or whole grain } \beta \text {-glucan enriched pasta: one } \\
\text { serving, three times a week }\end{array}$ & $256 \pm 58$ & 248 & 0.3653 \\
\hline Fat and oil & $5 \mathrm{~g}$ per slice of bread. $0.5 \mathrm{dl}$ oil for dressing per day & $32 \pm 7$ & 23 & $<0.0001$ \\
\hline Sweets and deserts ${ }^{\mathrm{m}}$ & For weekends & $38 \pm 11$ & 51 & $<0.0001$ \\
\hline Alcoholic beverages ${ }^{n}$ & Subjects habitual amount & $71 \pm 82$ & 177 & $<0.0001$ \\
\hline Beverages/liquids (non-alcohol) & $\begin{array}{l}\text { Free amount of tap water, tea, filtered coffee or instant coffee. } \\
\text { Juice from fruits, berries or vegetables: } 4 \mathrm{dl} \text { per week. Low alcohol } \\
\text { beer: one bottle }(33 \mathrm{cl}) \text { per day }\end{array}$ & $n a^{f}$ & $n a^{f}$ & $n a^{f}$ \\
\hline
\end{tabular}

The intake is expressed as mean \pm SD per day for ND and a mean value for SRP.

aSRP, Riksmaten 1997-1998. Dietary habits and nutrient intake in Sweden 1997-1998. The second national food consumption survey.

${ }^{\mathrm{b}} \mathrm{A}$ two-tailed $p<0.05$ was regarded as significant. Student's $t$-test, with the null hypothesis that the mean value for ND was equal to the fix value of SRP for each group of food items was used.

'ND includes rose hip, blueberry, lingonberry, apple, pear, prune, orange, cabbage, cauliflower, brussels sprouts, broccoli, fennel, spinach, kohlrabi, viper's grass, onion, leek, kale, sugar snaps, turnip, carrot, parsnip and beetroot. SRP includes fruit, berries, vegetables, root vegetables, potatoes and dishes thereof.

${ }^{\mathrm{d}}$ Of the $807 \mathrm{~g}$ consumed, potatoes compriced $73 \mathrm{~g}$.

eND includes brown beans, yellow and green peas, chickpeas, kidney bean and lentils. SRP includes legumes.

fNot applicable.

${ }^{\mathrm{g}} \mathrm{ND}$ includes beef, pork, lamb, sausages and poultry, such as chicken and turkey. SRP includes meat, poultry and sausages, and dishes thereof.

${ }^{\text {hOf the }} 89 \mathrm{~g}$ consumed, poultry comprised $50 \mathrm{~g}$.

'ND includes low-fat milk (0.5\%), whole milk (3\%), yoghurt (0.5-3\%), soured cream $(12 \%)$ and chocolate milk and cheese $(<I 7 \%)$. SRP includes milk, fermented milk, yoghurt and cheese.

'ND includes herring, Baltic herring, mackerel, salmon, sardine, caviar and egg. SRP includes fish, seafood, egg and dishes thereof.

${ }^{k} N D$ includes soft and hard bread rich in whole grain from rye and wheat, and oat bran rusks. Cold breakfast cereals, such as muesli and extruded oat bran, and hot breakfast cereals, such as porridge made of oat bran, oat meal or barley flakes and gruel, linseed, psyllium, sunflower seeds, pearled barley and oats (Mathavre, Matkorn), whole grain pasta, whole grain $\beta$-glucan-enriched pasta, maize, rice, bulgur and couscous. SRP includes bread, porridge, gruel, cereals, muesli, buns, biscuits, pasta and rice, and dishes thereof.

'ND includes vegetable low fat spread, no added plant sterols, vegetable liquid margarine for cooking and rapeseed oil for dressing. SRP includes edible fats and fat sauces.

${ }^{m} N D$ includes sweet-baked goods, sweets, sugar, syrup, ice cream and jam. SRP includes sweet soups, desserts, jam, marmalade, sweets and ice cream. ${ }^{\mathrm{n}} \mathrm{ND}$ and SRP include wine, beer and hard liquor.

the lower intake of meat products and poultry, dairy products, sweets, desserts, and alcoholic beverages in the ND.
Because of the uncertainty of the content of specific food products in the SRP, and the distributional properties of ND data (Table 2), the numbers should be 
Table 3. Mean intake of energy, nutrients and food components ( $n=44)$, after 6 weeks on ND compared to AR and RI, NNR 2004

\begin{tabular}{|c|c|c|c|}
\hline & ND & $\begin{array}{c}\mathrm{AR}^{\mathrm{a}} \\
\text { men/women }\end{array}$ & $\begin{array}{c}\mathrm{RI}^{\mathrm{b}} \\
\text { men/women }\end{array}$ \\
\hline Energy (kcal day ${ }^{-1}$ ) & 1,989 & $n a^{c}$ & $2,200^{d}$ \\
\hline Protein $\left(\mathrm{E} \%^{\mathrm{e}}\right)$ & 19 & $n a^{c}$ & $10-20$ \\
\hline Fat (E\%) & 27 & $\mathrm{na}^{\mathrm{c}}$ & $25-35$ \\
\hline Saturated fatty acids (E\%) & 5 & $\mathrm{na}^{\mathrm{c}}$ & $<8$ \\
\hline Mono-unsaturated fatty acids (E\%) & 11 & $n a^{c}$ & $12-17$ \\
\hline Polyunsaturated fatty acids (E\%) & 6 & $n a^{c}$ & $5-10$ \\
\hline Carbohydrate (E\%) & 52 & $\mathrm{na}^{\mathrm{c}}$ & $45-60$ \\
\hline Alcohol (E\%) & 2 & $\mathrm{na}^{\mathrm{c}}$ & $<5$ \\
\hline Vitamin $\mathrm{A}$, retinol equivalent $(\mu \mathrm{g})$ & 1,568 & $600 / 500$ & $900 / 700$ \\
\hline Vitamin $D^{a}(\mu g)$ & 8.0 & $5.2 / 5.2$ & 7.5/7.5 \\
\hline Tocopherol (mg) & 16 & $6 / 5 \mathrm{a}-\mathrm{TE}$ & I0/8 a-TE \\
\hline Thiamine (mg) & 1.6 & $1.2 / 0.9$ & I.4/I.I \\
\hline Riboflavin (mg) & 1.5 & $1.4 / 1.1$ & $1.7 / 1.3$ \\
\hline Niacin equivalent (mg) & 32 & $15 / 12 \mathrm{NE}$ & $19 / 15 \mathrm{NE}$ \\
\hline Vitamin B6 (mg) & 2.4 & $1.3 / 1.0$ & $1.6 / 1.2$ \\
\hline Vitamin $\mathrm{B} 12(\mu \mathrm{g})$ & 4.8 & $1.4 / 1.4$ & $2 / 2$ \\
\hline Folate $(\mu g)$ & 459 & $200 / 200$ & $300 / 300$ \\
\hline Vitamin C (mg) & 266 & $60 / 50$ & $75 / 75$ \\
\hline Calcium $^{\mathrm{a}}$ (mg) & 755 & $552 / 552$ & $800 / 800$ \\
\hline Phosphorus (mg) & $|, 39|$ & $450 / 450$ & $600 / 600$ \\
\hline Magnesium $^{\mathrm{a}}(\mathrm{mg})$ & 437 & $241 / 193$ & $350 / 280$ \\
\hline Iron (mg) & 15 & $7 / 10-6^{f}$ & $9 / 15-9$ \\
\hline Zinc (mg) & 10 & $6 / 5$ & $9 / 7$ \\
\hline Sodium (mg) & I,545 & $n a^{c}$ & $2,800 / 2,400$ \\
\hline Potassium ${ }^{\mathrm{a}}$ (mg) & 3.7 & $2.4 / 2.1$ & $3.5 / 3.1$ \\
\hline Selenium $(\mu \mathrm{g})$ & 39 & $35 / 30$ & $50 / 40$ \\
\hline Dietary cholesterol (mg) & $|3|$ & $n a^{c}$ & $<300^{g}$ \\
\hline Whole grain (g) & 111 & $n a^{c}$ & $90 / 70^{\mathrm{h}}$ \\
\hline Dietary fibre $(\mathrm{g})(\mathrm{g} / \mathrm{MJ})$ & $54(6.4)$ & $25-35(3)^{i}$ & $25-35(3)$ \\
\hline$\beta$-Glucan (g) & 4.9 & $\mathrm{na}^{\mathrm{c}}$ & $>3^{\mathrm{i}}$ \\
\hline Dietary fibre (fruit) (g) & 5 & $\mathrm{na}^{\mathrm{c}}$ & $\mathrm{na}^{\mathrm{k}}$ \\
\hline Dietary fibre (cereal) (g) & 23 & $n a^{c}$ & $\mathrm{na}^{\mathrm{k}}$ \\
\hline Cereal fibre (oat) (g) & 8.8 & $\mathrm{na}^{\mathrm{c}}$ & $\mathrm{na}^{\mathrm{k}}$ \\
\hline Cereal fibre (rye) (g) & 6.0 & $\mathrm{na}^{\mathrm{c}}$ & $\mathrm{na}^{\mathrm{k}}$ \\
\hline Cereal fibre (barley) (g) & 2.3 & $\mathrm{na}^{\mathrm{c}}$ & $\mathrm{na}^{\mathrm{k}}$ \\
\hline Cereal fibre (wheat) (g) & 5.5 & $\mathrm{na}^{\mathrm{c}}$ & $\mathrm{na}^{\mathrm{k}}$ \\
\hline Dietary fibre (vegetable) (g) & 15 & $\mathrm{na}^{\mathrm{c}}$ & $\mathrm{na}^{\mathrm{k}}$ \\
\hline Dietary fibre (legume) (g) & 5.0 & $\mathrm{na}^{\mathrm{c}}$ & $\mathrm{na}^{\mathrm{k}}$ \\
\hline
\end{tabular}

${ }^{a} A R$, according to the NNR. For micronutrients that had no AR in the NNR, an AR was calculated. First, the ratio AR/RI for micronutrients with both $A R$ and $R I$ in NNR was calculated. This ratio was used to calculate a proxy AR for vitamin D, calcium, magnesium and potassium.

${ }^{\mathrm{b}} \mathrm{RI}$ according to NNR.

$c_{\text {na }}=$ not applicable.

${ }^{\mathrm{d}}$ The ND was calculated to be isocaloric on a group level through validated formulas NNR 2004. The ND was given ad libitum, i.e., all participants were provided with the same number of calories, but they were at liberty to leave food or ask for more to match their individual needs.

${ }^{\mathrm{e}} \mathrm{E} \%=$ Percentage of daily energy intake.

fRefers to post-menopausal women.

${ }^{g}$ Reference (9).

hhttp://www.slv.se/sv/gruppl/Mat-och-naring/Kostrad/Vuxna/Fullkorn/09-0I-20I2.

'Analytical method, AOAC methods for total dietary fibre.

'Reference (29).

kThere is no RI for dietary fibre sources. 
considered as rough estimates, and, thus, interpreted with caution. Another uncertainty is that food consumption might have changed since the most recent food intake data of a random sample of a Swedish population in 1997-98 (32). According to the Swedish Board of Agriculture, during the period 2000-10, food consumption data indicate an increase in the consumption of fruit and berries $(3 \%)$, vegetables $(11 \%)$, meat and poultry $(19 \%)$ and bread and cereals, not including pastries (18\%), but during the same period, total consumption of milk and milk products decreased by $8 \%$ (33). These data suggest that since 1997-98, the difference between ND and a random sample of the Swedish population decreased with regard to fruits, berries and vegetables, bread and cereals, milk and milk products and increased with regard to meat and poultry consumption.

The relative intake of total fat, SFA, MUFA and PUFA in ND was in accordance with RI (Table 3). Lowfat products such as low-fat dairy products and lean meat together with low-fat cooking methods, such as oven baking and boiling, contributed to the reduced total fat and SFA content in the ND (Table 3). The main sources of fat contributing to the PUFA intake were rapeseed oil for dressing and cooking and a vegetable low-fat spread and vegetable liquid margarine based on sunflower oil, linseed oil and rapeseed oil for use on bread and for cooking. In the ND, the intake of fish, such as Baltic herring, herring, mackerel and salmon was $68 \mathrm{~g}$ per day, whereas, in SRP, the mean intake of fish and seafood, and dishes thereof, was $35 \mathrm{~g}$ per day for women and $34 \mathrm{~g}$ per day for men.

The replacement of foods rich in SFA and trans fatty acids with foods rich in PUFA has favourable effects on cardiovascular risk factors (22, 34-36). Although beneficial effects on diabetes risk and insulin sensitivity have been observed, the results are less consistent (37).

Rapeseed oil, with a high content of polyunsaturated fatty acids, has similar favourable effects on serum lipoprotein profile as olive oil (23). In hyperlipidemic subjects, rapeseed oil has more favourable effects on total cholesterol/high-density lipoprotein ratio and triglycerides than a diet rich in high-fat dairy products (22), especially when the diet consists of $>35 \mathrm{E} \%$ fat (22). In this study, total fat intake was much lower $(27 \mathrm{E} \%)$ and most likely explained the reduction in HDL-C (1). Future studies should aim for a total fat intake between 30-35 $\mathrm{E} \%$, with the majority of fat coming from plants and fish, i.e., both MUFA and PUFA $(35,36)$ to avoid reduction of HDL-C (22). The risk of developing CVD is reduced with a high consumption of fish $(4,38,39)$, i.e., around 1-2 servings per week. In high-risk populations, a fish consumption of 40-60 g per day is recommended; which could lead to approximately a $50 \%$ reduction in mortality from $\operatorname{CVD}(4,38)$.
The observed relative intake of $52 \mathrm{E} \%$ of carbohydrates in the ND was in accordance with RI by NNR (Table 3). When replacing SFA with carbohydrates, the effect on risk factors for CVD depends on the type of carbohydrates that replace SFA (40). In a prospective cohort study (40), the replacement of SFA with carbohydrates of low-GI value is associated with a lower risk of myocardial infarction, whereas replacing SFA with carbohydrates of high-GI value is associated with a higher risk of myocardial infarction. Although the GI of the ND was not measured, most carbohydrate-rich foods (e.g. pasta, pearled oat, pearled barley, brown beans, yellow and green peas) are low-GI foods (41).

The mean intake of dietary fibre in the ND was approximately twofold above RI (Table 3), with the major source of dietary fibre provided by cereal, vegetables, legumes and fruits (Table 3). Whole grain breakfast cereals, lunch and dinner cereals, porridge based on oat and barley and whole grain bread (50\% whole grain of dry matter) based on whole grain rye and wheat increased the intake of dietary fibre. The RI for a total cholesterol and LDL-C lowering effect of $\beta$-glucan from oat and barley is $3 \mathrm{~g}$ per day $(29,42-44)$, whereas, in the ND, the intake was $4.9 \mathrm{~g}$ per day. The higher intake of $\beta$-glucan on $\mathrm{ND}$, compared to the RI, might contribute to a larger portion of the reduction of total cholesterol (29).

The intake of whole grain, as an absolute amount, in the ND was above suggested recommendations $(5,45,46)$ and above actual whole grain intake in Scandinavia (Norway, Denmark, Sweden) where mean intake varies between 37 and $58 \mathrm{~g}$ per day (47). The high intake of whole grain in the ND was mainly explained by the high intake of whole grain breakfast cereals, oatmeal, barley meal, whole grain pasta, pearled oat, barley and both soft and hard whole grain bread. All traditionally consumed cereals, such as rye, oat, wheat and barley, were represented in the ND. Observational studies consistently suggest a lower risk of CVD and all-cause mortality (27, 48) with a high whole grain intake, although short-term controlled studies fail to show any effects on CVD risk factors $(49,50)$.

The $\mathrm{E} \%$ from protein was moderately higher in ND, but still in accordance with RI. The increased protein intake appeared to be mainly from vegetable sources, as the intake of meat and poultry was lower in ND than in SRP (Table 2). Thus, the substitution of animal protein sources for vegetable sources may reduce the risk of CVD $(51,52)$.

The low intake of sodium was in accordance with current dietary guidelines $(5,6,8,11)$, which was partly the result of replacing some sodium with potassium and magnesium in table salts and the use of various spices in cooking instead of table salt. 


\section{Conclusions}

The ND of the NORDIET study is mainly a plant-based diet, where animal products are used sparingly as side dishes. Compared with food intakes in an SRP, the ND is higher in absolute intake of fruits, berries, vegetables, root vegetables, potatoes, legumes, vegetable fats and oils, fish and eggs, but lower in meat products and poultry, dairy products, sweets and desserts and alcoholic beverages. The ND is a diet that fulfils current dietary recommendations regarding intake of micro- and macronutrients and includes food items readily available in most grocery stores in Sweden.

\section{Acknowledgements}

We thank Anders Persson, Rapport AB and Johan Eklund for the work with food data.

\section{Conflict of interest and funding}

This study was funded by a research grant from the Cerealia Foundation. VA received a research grant from the Cerealia Foundation R\&D, who financed the study. VA is a PhD student at Uppsala University, Sweden, and at the time of the study was employed by Lantmännen R\&D. GJ received a research grant from Cerealia Foundation R\&D to supervise VA in dietary survey methodology at the start of the study. UR was funded by a grant from the NordForsk Nordic Centre of Excellence of Food, Nutrition and Health (SYSDIET) and the Swedish Research Council and received research grants from Diabetesfonden and The Swedish Heart-Lung Foundation. TC is a professor in clinical nutrition at Uppsala University and received no external funding for participating in the study.

\section{References}

1. Adamsson V, Reumark A, Fredriksson IB, Hammarstrom E, Vessby B, Johansson G, et al. Effects of a healthy Nordic diet on cardiovascular risk factors in hypercholesterolaemic subjects: a randomized controlled trial (NORDIET). J Intern Med 2011; 269(2): 150-9.

2. de Mello VD, Schwab U, Kolehmainen M, Koenig W, Siloaho $\mathrm{M}$, Poutanen $\mathrm{K}$, et al. A diet high in fatty fish, bilberries and wholegrain products improves markers of endothelial function and inflammation in individuals with impaired glucose metabolism in a randomised controlled trial: the Sysdimet study. Diabetologia 2011; 54(11): 2755-67.

3. Lankinen M, Schwab U, Kolehmainen M, Paananen J, Poutanen K, Mykkanen $\mathrm{H}$, et al. Whole grain products, fish and bilberries alter glucose and lipid metabolism in a randomized, controlled trial: the Sysdimet study. PLoS One 2011; 6(8): e22646.

4. Diet, nutrition and the prevention of chronic diseases. World Health Organ Tech Rep Ser. 2003; 916: i-viii, 1-149, backcover.

5. Helsedirektoratet. (2011). Kostråd for å fremme folkhelsen og forebygge kroniske sykdommer. Metodologi og vitenskaplig kunnskapsgrunnlag. Nasjonalt råd for ernaering 2011. Oslo:
Avdelning for nasjonalt folkhelsearbeid. Report No.: IS-1881 Contract No.: IS-1881.

6. Becker W, Lyhne N, Pedersen A, Aro A, Fogelholm M, Thórsdottír I. Nordic Nutrition Recommendations 2004. Integrating nutrition and physical activity. Copenhagen: Nordic Council of Ministers; 2004.

7. Lichtenstein AH, Appel LJ, Brands M, Carnethon M, Daniels $\mathrm{S}$, Franch HA, et al. Diet and lifestyle recommendations revision 2006: a scientific statement from the American Heart Association Nutrition Committee. Circulation 2006; 114(1): 82-96.

8. US Department of Health and Human Services, US Department of Agriculture, US Dietary Guidelines Advisory Committee. (2010). Dietary guidelines for Americans, 2010. Washington, DC: US Department of Health and Human Services, US Department of Agriculture. Available: http://www.cnpp.usda. gov/DGAs2010-PolicyDocument.htm

9. Flock MR, Kris-Etherton PM. Dietary guidelines for Americans 2010: implications for cardiovascular disease. Curr Atheroscler Rep 2011; 13(6): 499-507.

10. Appel LJ, Moore TJ, Obarzanek E, Vollmer WM, Svetkey LP, Sacks FM, et al. A clinical trial of the effects of dietary patterns on blood pressure. DASH Collaborative Research Group N Engl J Med 1997; 336(16): 1117-24.

11. Sacks FM, Svetkey LP, Vollmer WM, Appel LJ, Bray GA, Harsha D, et al. Effects on blood pressure of reduced dietary sodium and the dietary approaches to stop hypertension (DASH) diet. DASH-Sodium Collaborative Research Group N Engl J Med 2001; 344(1): 3-10.

12. Whelton PK, He J, Appel LJ, Cutler JA, Havas S, Kotchen TA, et al. Primary prevention of hypertension: clinical and public health advisory from The National High Blood Pressure Education Program. JAMA 2002; 288(15): 1882-8.

13. Sofi F, Cesari F, Abbate R, Gensini GF, Casini A. Adherence to Mediterranean diet and health status: meta-analysis. BMJ 2008; 337: a1344.

14. Tuomilehto J, Lindstrom J, Eriksson JG, Valle TT, Hamalainen $\mathrm{H}$, Ilanne-Parikka P, et al. Prevention of type 2 diabetes mellitus by changes in lifestyle among subjects with impaired glucose tolerance. N Engl J Med 2001; 344(18): 1343-50.

15. Lindstrom J, Louheranta A, Mannelin M, Rastas M, Salminen $\mathrm{V}$, Eriksson J, et al. The Finnish Diabetes Prevention Study (DPS): lifestyle intervention and 3-year results on diet and physical activity. Diabetes Care 2003; 26(12): 3230-6.

16. World Cancer Research Fund/American Institute for Cancer Research (2007). Food, nutrition, physical activity and the prevention of cancer: a Global Perspective. Washington, DC: AICR.

17. Olsen A, Egeberg R, Halkjaer J, Christensen J, Overvad K, Tjonneland A. Healthy aspects of the Nordic diet are related to lower total mortality. J Nutr 2011; 141(4): 639-44.

18. Mithril C, Dragsted LO, Meyer C, Blauert E, Holt MK, Astrup A. Guidelines for the new Nordic diet. Public Health Nutr 2012: 1-7.

19. Sjogren P, Becker W, Warensjo E, Olsson E, Byberg L, Gustafsson IB, et al. Mediterranean and carbohydrate-restricted diets and mortality among elderly men: a cohort study in Sweden. Am J Clin Nutr 2010; 92(4): 967-74.

20. Huijbregts P, Feskens E, Räsänen L, Fidanza F, Nissinen A, Menotti A, et al. Dietary pattern and 20 year mortality in elderly men in Finland, Italy, and the Netherlands: longitudinal cohort study. BMJ 1997; 315(7099): 13-7.

21. Trichopoulou A, Orfanos P, Norat T, Bueno-de-Mesquita B, Ocke MC, Peeters PH, et al. Modified Mediterranean diet and survival: EPIC-elderly prospective cohort study. BMJ 2005; 330(7498): 991. 
22. Iggman D, Gustafsson IB, Berglund L, Vessby B, Marckmann P, Riserus U. Replacing dairy fat with rapeseed oil causes rapid improvement of hyperlipidaemia: a randomized controlled study. J Intern Med 2011; 270(4): 356-64.

23. Nydahl M, Gustafsson IB, Ohrvall M, Vessby B. Similar effects of rapeseed oil (canola oil) and olive oil in a lipid-lowering diet for patients with hyperlipoproteinemia. J Am Coll Nutr 1995; 14(6): 643-51.

24. Willett WC, Sacks F, Trichopoulou A, Drescher G, Ferro-Luzzi A, Helsing E, et al. Mediterranean diet pyramid: a cultural model for healthy eating. Am J Clin Nutr 1995; 61(Suppl 6): 1402S-6S.

25. Gardner CD, Coulston A, Chatterjee L, Rigby A, Spiller G, Farquhar JW. The effect of a plant-based diet on plasma lipids in hypercholesterolemic adults: a randomized trial. Ann Intern Med 2005; 142(9): 725-33.

26. Flight I, Clifton P. Cereal grains and legumes in the prevention of coronary heart disease and stroke: a review of the literature. Eur J Clin Nutr 2006; 60(10): 1145-59.

27. Harris KA, Kris-Etherton PM. Effects of whole grains on coronary heart disease risk. Curr Atheroscler Rep 2010; 12(6): $368-76$.

28. Wolever TM, Tosh SM, Gibbs AL, Brand-Miller J, Duncan AM, Hart V, et al. Physicochemical properties of oat betaglucan influence its ability to reduce serum LDL cholesterol in humans: a randomized clinical trial. Am J Clin Nutr 2010; 92(4): 723-32.

29. Tiwari U, Cummins E. Meta-analysis of the effect of betaglucan intake on blood cholesterol and glucose levels. Nutrition 2011; 27(10): 1008-16.

30. Lundin EA, Zhang JX, Lairon D, Tidehag P, Aman P, Adlercreutz H, et al. Effects of meal frequency and high-fibre rye-bread diet on glucose and lipid metabolism and ileal excretion of energy and sterols in ileostomy subjects. Eur J Clin Nutr 2004; 58(10): 1410-9.

31. Jenkins DJ, Josse AR, Wong JM, Nguyen TH, Kendall CW. The portfolio diet for cardiovascular risk reduction. Curr Atheroscler Rep 2007; 9(6): 501-7.

32. Becker W, Pearson M. Riksmaten (1997-98). Dietary habits and nutrient intake in Sweden 1997-98. The Second National Food Consumption Survey. Available: http://www.slv.se/en-gb/Group1/ Food-and-Nutrition/Dietary-surveys1/Riksmaten-1997-98-Dietaryhabits-and-nutrient-intake-in-Sweden

33. Swedish Board of Agriculture. 2012. Livsmedelskonsumtion och näringsinnehåll. Available: http://www.sjv.se/webdav/files/SJV/ Amnesomraden/Statistik $\% 2 \mathrm{C} \% 20 \mathrm{fakta} /$ Livsmedel/Statistikrapport 2012_1/Statistikrapport2012_1/201201._inEnglish.htm

34. Mozaffarian D, Micha R, Wallace S. Effects on coronary heart disease of increasing polyunsaturated fat in place of saturated fat: a systematic review and meta-analysis of randomized controlled trials. PLoS Med 2010; 7(3): e1000252.

35. Mensink RP, Katan MB. Effect of dietary fatty acids on serum lipids and lipoproteins. a meta-analysis of 27 trials. Arterioscler Thromb 1992; 12(8): 911-9.

36. Erkkilä A, de Mello VDF, Risérus U, Laaksonen DE. Dietary fatty acids and cardiovascular disease: an epidemiological approach. Prog Lipid Res 2008; 47(3): 172-87.

37. Riserus U, Willett WC, Hu FB. Dietary fats and prevention of type 2 diabetes. Prog Lipid Res 2009; 48(1): 44-51.

38. Kromhout D, Bosschieter EB, de Lezenne Coulander C. The inverse relation between fish consumption and 20-year mortality from coronary heart disease. N Engl J Med 1985; 312(19): 1205-9.

39. Mozaffarian D. Fish and n-3 fatty acids for the prevention of fatal coronary heart disease and sudden cardiac death. Am J Clin Nutr 2008; 87(6): 1991S-6S.

40. Jakobsen MU, Dethlefsen C, Joensen AM, Stegger J, Tjonneland A, Schmidt EB, et al. Intake of carbohydrates compared with intake of saturated fatty acids and risk of myocardial infarction: importance of the glycemic index. Am J Clin Nutr 2010; 91(6): 1764-8.

41. Foster-Powell K, Holt SH, Brand-Miller JC. International table of glycemic index and glycemic load values: 2002. Am J Clin Nutr 2002; 76(1): 5-56.

42. United States Food and Drug Administration. Food labelling: health claims; soluble dietary fiber from certain foods and coronary heart disease. Interim final rule. Fed Regist 2002; 67: 617773-83.

43. Abumweis SS, Jew S, Ames NP. Beta-glucan from barley and its lipid-lowering capacity: a meta-analysis of randomized, controlled trials. Eur J Clin Nutr 2010; 64(12): 1472-80.

44. Wood PJ. Cereal B-glucans in diet and health. J Cereal Sci 2007; 46: $230-8$.

45. National Food Agency. 2012. Fullkorn. Available: http:// www.slv.se/sv/grupp1/Mat-och-naring/Kostrad/Vuxna/Fullkorn

46. The Danish Veterinary and Food Administration F. De 8 kostråd 2011. Available: http://www.altomkost.dk/Anbefalinger/ De_8_kostraad/forside.htm

47. Kyro C, Skeie G, Dragsted LO, Christensen J, Overvad K, Hallmans G, et al. Intake of whole grain in Scandinavia: intake, sources and compliance with new national recommendations. Scand J Public Health 2012; 40(1): 76-84.

48. Park Y, Subar AF, Hollenbeck A, Schatzkin A. Dietary fiber intake and mortality in the NIH-AARP diet and health study. Arch Intern Med 2011; 171(12): 1061-8.

49. Andersson A, Tengblad S, Karlstrom B, Kamal-Eldin A, Landberg R, Basu S, et al. Whole-grain foods do not affect insulin sensitivity or markers of lipid peroxidation and inflammation in healthy, moderately overweight subjects. J Nutr 2007; 137(6): 1401-7.

50. Brownlee IA, Moore C, Chatfield M, Richardson DP, Ashby P, Kuznesof SA, et al. Markers of cardiovascular risk are not changed by increased whole-grain intake: the WHOLEheart study, a randomised, controlled dietary intervention. Br J Nutr 2010; 104(1): 125-34.

51. Clifton PM. Protein and coronary heart disease: the role of different protein sources. Curr Atheroscler Rep 2011; 13(6): 493-8.

52. Bernstein AM, Sun Q, Hu FB, Stampfer MJ, Manson JE, Willett WC. Major dietary protein sources and risk of coronary heart disease in women. Circulation 2010; 122(9): 876-83.

*Viola Adamsson
Clinical Nutrition and Metabolism
Department of Public Health and Caring Sciences
Uppsala University
Uppsala Science Park
SE-75I 85 Uppsala
Sweden
Tel: +46702067732
Email: viola.adamsson@pubcare.uu.se

